RESEARCHARTICLE

\title{
A Multi-disciplinary Empirical Investigation of Active Learning Classroom's Effects on Student Learning
}

\author{
Xiaoshan Zhu Gordy ${ }^{1 *}$, Lei Zhang' ${ }^{2}$, Amy L. Sullivan, Lisa Haynie ${ }^{2}$, La'Toya Richards- \\ Moore ${ }^{4}$, and Jessica H. Bailey ${ }^{4}$
}

${ }^{1}$ School of Graduate Studies, University of Mississippi Medical Center, USA

${ }^{2}$ School of Nursing, University of Mississippi Medical Center, USA

${ }^{3}$ School of Dentistry, University of Mississippi Medical Center, USA

${ }^{4}$ School of Health Related Professions, University of Mississippi Medical Center, USA

\begin{abstract}
Technology has been recognized by U.S. Department of Education as a powerful tool to engage students and facilitate learning. Many institutions are making conscious efforts in incorporating technology into classrooms through transforming traditional classrooms (TCS) into technology-rich active learning classrooms (ALCS), in hope of making a positive impact on student learning. In 2014, a school within a U.S. southeastern academic medical center renovated a traditional classroom and converted it into an ALC called the Collaboratory. In this study, we surveyed 275 students who took weekly classes in the Collaboratory to compare their perceptions regarding ability to focus, classroom interaction, group work, and the development of creativity in the ALC and TCs respectively. We also conducted a cohort investigation into course grades of two consecutive courses taught by the same instructor in both the new ALC and TCs by comparing four-year TC grades with one-year ALC grades. Our findings indicated that students perceived the ALC and TCs differently with respect to their ability to maintain concentration, peer interaction, group work efficiency, and the development of creativity. The ALC gained higher mean scores than TCs in all those aspects. In addition, our cohort course grade comparisons demonstrated that the mean scores increased between grades earned in the ALC and TCS but the differences were not significant. Factors that could have possibly contributed to the insignificant change on grades were also discussed.
\end{abstract}

Sullivan, A.L., Haynie, L., Richards-Moore, L., Bailey, J.H.(2018). A Multi-Disciplinary Empirical Investigation of Active Learning Classroom's Effects on Student Learning. Interdisciplinary Education and Psychology, 2(1):3.

Received: October 18, 2017

Accepted: January 25, 2018

Published: February 5, 2018

Copyright: $\odot 2018$ Gordy et al. This is an open access article distributed under the terms of the Creative Commons Attribution License, which permits unrestricted use, distribution, and reproduction in any medium, provided the original author and source are credited.

\section{Corresponding author:}

Xiaoshan Zhu Gordy, School of Graduate Studies, University of Mississippi

Medical Center, USA.

E-mail: xgordy@umc.edu

\section{Keywords}

Active learning classroom, focus, interaction, group work, creativity

\section{Introduction}

Technology has undoubtedly permeated every aspect of our daily lives. Its ubiquitous availability today has put education systems of all levels at an unprecedented advantage with access to boundless information and possibility of new exploration and invention. Many educators believed that technology could potentially transform learning environments from passive to active, which would help enable students to become more actively involved in their learning (Lowerison, Sclater, Schmid, \& Abrami, 2006; Roblyer, 2003). Since 2010, U.S. Department of Education has issued a series of National Education Technology Plans (U.S. Department of Education, 2010, 2016, 2017). These plans recognized that technology could be a powerful tool to assist learning and urged all education stakeholders to use technology effectively to improve American education. To better incorporate technology into education, many institutions in higher education are investing in redesigning traditional classrooms (TCs) into technology-rich active learning classrooms (ALCs), with the expectation of making an influential impact on student learning (Hunley \& Schaller, 2006). These ALCs typically 
feature multiple flat-panel screens or projectors, movable furniture, and advanced portable device-based technology.

In 2014, a school within a U.S. southeastern academic medical center transformed a traditional classroom into an ALC named the Collaboratory (see definition in Figure 1). When compared to a typical traditional classroom, the design of the Collaboratory was of a total overhaul. It was equipped with 12 large interconnected flat screens, a large wall projector, rectangular and semicircular movable tables with access points to power outlets and smart device hookups, individual swivel chairs with built-in work surfaces and storage in the tripod base, both large and small portable white boards on rollers. For instructors, this space has offered them opportunities to quickly switch from one mode of teaching (e.g. lecturing) to another (e.g. individual or group work). For students, this space has provided an unobstructed view of class content from anywhere in the room, allowed connectivity and mobility, and enabled dynamic collaboration and interactive learning.

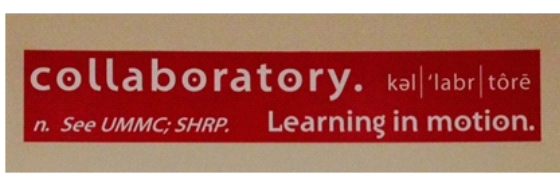

Figure 1. Definition of Collaboratory

Even though the adoption of technology-rich classroom design remains slow today, avantgarde educators started research in this field over a decade ago. The primary examples in the U.S. included North Carolina State University's Student-Centered Activities for Large Enrollment Undergraduate Physics (SCALE-UP) project (Beichner et al., 2007; Beichner, Saul, Allain, Deardorff, \& Abbott, 2000), Massachusetts Institute of Technology's Technologyenabled active learning (TEAL) project (Dori \& Belcher, 2005; Dori et al., 2003), and the University of Minnesota's Active Learning Classrooms (ALCs) research (Baepler \& Walker, 2014; Brooks, 2011, 2012; Brooks \& Solheim, 2014). The SCALE-UP Project results showed that interactive learning environments improved students' problem-solving skills, attitude development, class attendance rates, and reduced failure rates. The TEAL project found that students involved in TEAL demonstrated improved conceptual understanding and lower failure rates. The ALC research by the University of Minnesota discovered that active learning spaces alone had significant and positive impact on student learning. Similar research has also recently been conducted in other countries around the globe, such as Korea (Park \& Choi, 2014), Hongkong (Chiu \& Cheng, 2017), Canada (Chen, 2015; Gebre, Saroyan, \& Aulls, 2015). They discovered that active learning environments were more inspirational than traditional classrooms and more conducive to students' critical thinking or open-minded thinking skills. These existing studies were conducted in various disciplines such as finance, biology, physics, chemistry, and education. However, we were not aware of published studies of ALCs in allied health educational settings. Moreover, many of the existing research focused on only perceptional measures. A few provided empirical evidences on ALCs' impact on learning outcomes. Building upon previous research, in this study we collected data from both perceptional and empirical perspectives aiming to gain a more holistic view, narrow the gap in the literature, and provide a deeper insight into the effectiveness of ALCs.

\section{Methods}

Since the Collaboratory was put in use, faculty and administrators were eager to find out how the room affected teaching and learning and whether it made a positive academic impact. In a recent qualitative study with faculty and students from various disciplines (Gordy, Jones, \& Bailey, 2018), our findings indicated that the Collaboratory promoted student engagement, increased classroom interaction, enhanced group work efficiency, and fostered the development of creativity. To cross-validate the qualitative findings, we referred to a quantitative measurement - student survey - to see whether students' perceptions of the Collaboratory regarding those aspects were consistent with our qualitative findings. In the meantime, we sought to investigate whether teaching and learning in the Collaboratory yielded better student learning outcomes through comparing course grades earned in the Collaboratory and TCs respectively. All research activities involved in the study were approved by the Institutional Review Board at the current medical center.

\section{Student Survey}

The student survey in the current study contained 25 questions that were adapted from Park 
and Choi's study (2014). The survey was shared by one of the authors and was originally in Korean. It was then translated and sent back, along with adaptions made suitable for the current study, to the Korean authors for verification of accuracy and advice. The final survey included four demographical questions, two academic attitudinal questions, fifteen educational effects questions comparing the ALC and TC which required responses on fivepoint Likert scale, and four open-ended questions related to students' learning space experiences. All of the questions were entered into a survey software (Qualtrics) and an online survey was generated through the tool.

In this study, we did not intend to survey students who took occasional classes in the Collaboratory, as they might not have in-depth experiences with the room to give valid answers. In order to find out which students took weekly classes in the Collaboratory, we inquired into the Collaboratory schedule at the beginning of 2015-2016 academic year and identified five instructors who were scheduled to teach classes in the room every week. The corresponding students in those five instructors' classes, 275 in total, were then identified as the sample for our survey. They were from five different allied health disciplines: Dental Hygiene (DH), Physical Therapy (PT), Occupational Therapy (OT), Medical Laboratory Sciences (MLS), Radiologic Sciences (RS). The students were surveyed towards the end of the academic year when they had almost a full year of experience in the Collaboratory. The survey was anonymous and completely voluntary. A total of 246 , nearly $90 \%$ of the students, responded. After excluding 12 incomplete ones, we extracted 234 (85.1\%) valid student responses. In the current study, only questions pertinent to our research questions were included for analysis.

\section{Course Grades}

To find out whether the design of the Collaboratory was more conducive to student learning outcomes, we intended to compare course grades earned in the Collaboratory from the 2015-2016 academic year with five-year historical grades (2010-2015) of the same courses taught by the same instructors in the TCs. After checking with all five instructors mentioned previously, one was not to give numerical grades (only "pass" or "fail"), two were only to teach a portion of their courses in the Collaboratory (other portions were taught in the TCs or labs), and one never taught in the TC before to offer historical data, so they were excluded from the study. The instructor in dental hygiene was scheduled to teach two consecutive courses (Dental Radiology I and II) in the Collaboratory in the 2015-2016 academic year. Prior to that, she had taught the same two courses in the traditional setting for five years. Therefore, grades from her classes were the only suitable ones for our study. For the study purpose, she graciously agreed, per our request at the beginning of the fall semester, not to change class content, teaching styles and tests so that we could control as many variables as possible. We followed the instructor for the entire academic year to make class observations in the Collaboratory. At the end of the academic year, we collected grades from current and historical courses. After further examining the historical data, we excluded the grades from 2010-2011 year because the courses were combined in one at the time. Therefore, four-year historical grades earned in the TCs by 80 students and one-year grades earned in the Collaboratory by 19 students were included in the final analysis.

\section{Data Management and analysis}

The survey data were exported in SPSS format from Qualtrics. All analyses were conducted using IBM SPSS Statistics 23. Independent-samples $t$-tests were used to compare the results of students' perceptions towards educational effects of ALC and TC. The same tests were used to compare the course grades earned in those two separate classroom settings. The statistical tests were considered significant if $p$-values from the tests were less than 0.05 . All tests were two sided.

\section{Results}

The majority of students who answered the survey came from the PT program (44\%). More than $70 \%$ of students were female. Over $80 \%$ of students were white, and about two-thirds $(67 \%)$ had an incoming GPAin the range of 3.5 to 3.9 .

\section{Design of the Collaboratory and Classroom Improvement}

Table 1 presents student responses to five survey questions that are related to our research interest. In these questions, participants were asked how strongly they agreed or disagreed 
with the same statement twice, once for how the statement applied to TC and once for how it applied to ALC. Mean scores by classroom type (strongly agree =5, strongly disagree =1), differences of mean scores and p-value from independent $t$-tests are shown.

From Table 1, we can see that students' perception regarding whether they could concentrate for a long time differed by classroom type $(p<0.001)$. ALC received a mean score of 3.70 , about $28.5 \%$ higher than TC (2.88). Two questions were asked regarding classroom interaction, one on peer interaction and one on student-teacher interaction. The results indicated that students' attitudes toward the easiness of peer interaction differed by the classroom type $(p<0.001)$. ALC again had a higher mean score of 4.29 , compared to 3.38 for TC. As to student-teacher interaction, no significant difference $(p=0.193)$ was found between two types of classrooms. Student attitudes toward the efficiency of learning space differed significantly ( $p<0.001)$ with the highest mean difference $(1.3)$ among all the five questions. ALC achieved a mean score of 4.36 , whereas TC only had a mean score of 3.06 . In regard to the development of creative ideas, students' answers differed significantly by classroom type as well $(p<0.001)$. ALC demonstrated a mean score of 4.22 , about $22.0 \%$ higher than TC (3.46).

\section{Design of the Collaboratory and the Learning Outcomes}

The Dental Hygiene program enrolled about 20 students per year. In the past five years, mainly females chose the profession, with only two male students enrolled. Approximately $85 \%$ of the students were under 25 years old. Three quarters of them were white. Almost $60 \%$ of the students scored between 20 and 24 in ACT and half of them had an incoming GPA in the range of 3.0 to 3.4 .

Dental Hygiene is a lockstep program, and Dental Radiology I and II were required courses in the first year of the program. From Table 2, we can see a slight mean score increase between grades earned in TC and ALC, 1.5 for Dental Radiology I (TC: M=85.2, SD=5.3; ALC: $M=86.7, S D=5.5$ ) and 1.6 for Dental Radiology II (TC: $M=85.2, S D=5.3$; $A L C: M=86.7$, $S D=5.5)$. However, the increases were not significant (Dental Radiology I, t (97) = -1.096, $p=$ 0.276; Dental Radiology II, t $(97)=-1.598, p=0.113)$.

Table 1. Survey responses to research questions $(\mathrm{N}=234)$

\begin{tabular}{|c|c|c|c|c|}
\hline Survey Questions & Classroom Type & Mean & ACT-TC & P-value \\
\hline \multirow{2}{*}{$\begin{array}{l}\text { I can maintain my concentration in class for a long } \\
\text { time. }\end{array}$} & TC & 2.88 & 0.92 & $<0.001$ \\
\hline & ALC & 3.70 & & \\
\hline \multirow{2}{*}{$\begin{array}{l}\text { It's easy to exchange information and share different } \\
\text { viewpoints with other students. }\end{array}$} & TC & 3.38 & 0.91 & $<0.001$ \\
\hline & ALC & 4.29 & & \\
\hline \multirow[t]{2}{*}{ It's easy to interact with the instructor. } & $\mathrm{TC}$ & 3.95 & 0.10 & $=0.193$ \\
\hline & ALC & 4.05 & & \\
\hline \multirow{2}{*}{$\begin{array}{l}\text { The learning space enhances the efficiency of group } \\
\text { projects. }\end{array}$} & $\mathrm{TC}$ & 3.06 & 1.30 & $<0.001$ \\
\hline & ALC & 4.36 & & \\
\hline \multirow{2}{*}{$\begin{array}{l}\text { The learning environment is conducive to the } \\
\text { development of creative ideas. }\end{array}$} & $\mathrm{TC}$ & 3.46 & 0.76 & $<0.001$ \\
\hline & ALC & 4.22 & & \\
\hline
\end{tabular}


Table 2. Independent-samples $t$-tests Comparing Dental Radiology I and II Grades Earned in TC and ALC

\begin{tabular}{cccccc}
\hline Course & Classroom Type & Academic Year & Mean & SD & $P$-value \\
\hline Dental Radiology I & TC & Fall 2011- 2014 & 85.2 & 5.3 & \multirow{2}{*}{0.276} \\
\cline { 2 - 5 } & ALC & Fall 2015 & 86.7 & 5.5 & \\
\hline Dental Radiology II & TC & Spring 2012-2015 & 86.2 & 3.7 & 0.104 \\
\cline { 2 - 5 } & ALC & Spring 2016 & 87.8 & 4.9 & \\
\hline
\end{tabular}

\section{Discussion}

Students' attention span is roughly fifteen minutes (Wankat, 2002). After that, most students' attention level tends to drop dramatically resulting in declined knowledge retention (Hartley \& Davies, 1978; Newble \& Cannon, 1995). Our results suggested that more students believed that they could stay focused for a long time in the classroom setting of ALC than TCs, which is consistent with Park and Choi's finding (2014). This could be the result of natural occurrences of increased peer interaction and group activities in the ALC. The presence of those activities broke lectures into segments and engaged students' visual, auditory, and kinesthetic (VAK) senses, which herein helped involve students in the learning process and keep them focused longer (Whiteley, 2007).

The results of this study suggested that students perceived that information sharing with peers was easier in the ALC than TCs. This concurred with both Park and Choi's finding (2014) and Brooks' (Brooks, 2012) research findings. However, as to student-teacher interaction, the ALC and TCs were on a par.The increased peer interaction in the ALC could be induced by easiness of moving about, screen sharing capability, and face-to-face seating arrangement. The similar amount of student-teacher interaction in the ALC and TCs was actually a positive finding as it indicated that instructors made themselves available regardless of the classroom types.

The results of the current study also indicated that more students agreed that learning space like ALC enhanced the efficiency of group work. Group work has been exalted as an effective teaching approach and its positive effects on student engagement, knowledge retention, and the development of work-related skills have been reported in numerous studies (Bonwell \& Eison, 1991; Puma \& Abt Associates, 1996; Sherman, 1991; Smith \& Cardaciotto, 2011; Swaray, 2012). This finding was expected as the intention of the ALC design was to allow instructors to be able to quickly huddle or break out for different types of group work.

Studies on the importance of creativity has been long established in the literature and it was believed that individuals with creative talent tended to display a love for challenges, higher satisfaction from what they were doing, and greater lifetime achievements (Guilford, 1950, 1977; Mackinnon, 1962; Torrance, 1966; Torrance, 1970; Torrance, 1983).In Bloom's Taxonomy (Anderson et al., 2001), creativity has been placed on the top of the learning pyramid and considered as the ultimate learning objective. Making learning environments a breeding ground for creativity has become one of highly valued but yet often unfulfilled educational goals (Beghetto \& Kaufman, 2014). The fact that the majority of students considered the ALC conducive to the development of creativity implies that ALCs hold promises for realizing this educational goal and paving the road for students' future success.

The cohort comparison of course grades earned in the ALC and TCs for both courses displayed a slight mean score increase but no statistical differences, which was contradictory to many previous studies and definitely added a different voice to the body of existing literature. Several factors may have contributed to this result. First, the overall student population was small due to the limited enrollment size in the dental hygiene program at the current institution. Second, we only collected one-year course grades earned in the ALC when both the instructor and students were at the stage of groping for better utilization of the room. Continuing to collect data for a few more years with increased sample size might lead to results that are more promising. Third, the instructor was asked not to change her class content, teaching styles and tests so that we could better test the effects of the ALC. This may have limited the usage of the classroom facilities to their full extent. Fourth, the tests used for both courses may have been designed to evaluate student learning in TCs but may not 
appropriately reflect student gains from the ALC.

There are some limitations to this study. First, the ALC under study was the first and only one at the institution. The novelty of the design could have contributed to some positive perceptions but may wear off over time. Second, the study was quasi-experimental as random sampling was not applicable, especially in the selection of sample for course grade comparison. Larger sample size or longer study duration might produce a more convincing outcome. Third, teaching in a totally different environment was inherently such a complex phenomenon that it was impossible to single out any confounding factors to fully evaluate the effect of the space alone.

In conclusion, the current study indicated that student perceptions with respect to their ability to maintain concentration, peer interaction, group work efficiency and the development of creativity differed significantly by the classroom type. The active learning space gained higher mean scores than traditional settings in all of those aspects. However, no significant differences were found from grades earned in the ALC and TCs. Future educators are encouraged to employ ALC appropriate teaching approaches to optimize student learning. They are also encouraged to design ALC appropriate tests to effectively evaluate student learning. Moreover, future research should be conducted with a larger sample size at multiple educational settings to further investigate the impact of active learning classrooms in order to better enlighten forthcoming pedagogical reform and classroom redesign.

\section{Acknowledgements}

The authors would like to acknowledge Dr. Elizabeth Carr for her generous help throughout this research.

\section{Funding Information}

This study did not require any type of funding. The Collaboratory was constructed before the study.

\section{Conflict of Interest}

The authors of this article have no affiliations with or involvement in any organization or entity with any financial interest, or non-financial interest in the subject matter discussed in this manuscript.

\section{Supplemental Materials}

1. Survey: http://uofmississippi.qualtrics.com/jfe/form/SV_b8gRrm5ZIgGNCC1

2. Categorical frequency test results of survey questions:

\begin{tabular}{|c|c|c|c|c|}
\hline Survey Questions & $\begin{array}{l}\text { Classroom } \\
\text { Type }\end{array}$ & $\begin{array}{l}\text { Strongly } \\
\text { agree/agree } \\
\mathrm{n}(\%)\end{array}$ & $\begin{array}{l}\text { Neither } \\
\text { agree nor } \\
\text { disagree } \\
\mathrm{n}(\%)\end{array}$ & $\begin{array}{l}\text { Disagree / } \\
\text { Strongly } \\
\text { disagree } \\
\mathrm{n}(\%)\end{array}$ \\
\hline \multirow{2}{*}{$\begin{array}{l}\text { I can maintain my concentration in } \\
\text { class for a long time. }\end{array}$} & TC & $75(32.0)$ & $55(23.5)$ & $104(44.4)$ \\
\hline & ALC & $156(66.7)$ & $52(22.2)$ & $26(11.1)$ \\
\hline \multirow{2}{*}{$\begin{array}{l}\text { It's easy to exchange information } \\
\text { and share different viewpoints } \\
\text { with other students. }\end{array}$} & TC & $119(50.9)$ & $60(25.6)$ & $55(23.5)$ \\
\hline & ALC & $209(89.3)$ & $21(9.0)$ & $4(1.7)$ \\
\hline \multirow{2}{*}{$\begin{array}{l}\text { It's easy to interact with the } \\
\text { instructor. }\end{array}$} & TC & $189(80.8)$ & $33(14.1)$ & $12(5.1)$ \\
\hline & ALC & $198(84.6)$ & $25(10.7)$ & $11(4.7)$ \\
\hline \multirow{2}{*}{$\begin{array}{l}\text { The learning space enhances the } \\
\text { efficiency of group projects. }\end{array}$} & TC & $87(37.2)$ & $62(26.5)$ & $85(36.3)$ \\
\hline & ALC & $216(92.3)$ & $15(6.4)$ & $3(1.3)$ \\
\hline \multirow{2}{*}{$\begin{array}{l}\text { The learning environment is } \\
\text { conducive to the development of } \\
\text { creative ideas. }\end{array}$} & TC & $120(51.3)$ & 77 (32.9) & $37(15.8)$ \\
\hline & ALC & $211(90.2)$ & $19(8.1)$ & $4(1.7)$ \\
\hline
\end{tabular}




\section{References}

Anderson, L. W., Krathwohl, D. R., Airasian, P. W., Cruikshank, K. A., Mayer, R. E., Pintrich, P. R., . . . Wittrock, M. C. (2001). A Taxonomy for Learning, Teaching, and Assessing: A Revision of Bloom's Taxonomy of Educational Objectives (L. W. Anderson \& D. R. Krathwohl Eds.). New York: Pearson, Allyn \& Bacon.

Baepler, P., \& Walker, J. D. (2014). Active Learning Classrooms and Educational Alliances: Changing Relationships to Improve Learning. New Directions for Teaching \& Learning, 137, 27-40. doi:10.1002/tl.20083

Beghetto, R. A., \& Kaufman, J. C. (2014). Classroom Contexts for Creativity. High Ability Studies, 25(1), 53-69. Retrieved from http://search.ebscohost.com/login.aspx?direct=true\&db=eric\&AN=EJ1 031196\&site=ehost-live

Beichner, R. J., Saul, J. M., Abbott, D. S., Morse, J., Deardorff, D., Allain, R. J., . . Risley, J. S. (2007). The student-centered activities for large enrollment undergraduate programs (SCALE-UP) project. Research-based Reform of University Physics, 1(1), 2-39.Retrieved from http://www.percentral. com/PER/per_reviews/media/volume1/SCALE-UP-2007.pdf

Beichner, R. J., Saul, J. M., Allain, R. J., Deardorff, D. L., \& Abbott, D. S. (2000). Introduction to SCALEUP: Student-Centered Activities for Large Enrollment University Physics. Retrieved from http://search.ebscohost.com/login.aspx?direct=true\&db=eric\&AN=ED459062\&site=ehost-live

Bonwell, C. C., \& Eison, J. A. (1991). Active Learning: Creating Excitement in the Classroom. 1991 ASHE-ERIC Higher Education Reports. Washington D. C.: Association for the Study of Higher Education - Eric Clearinghouse on Higher Education.

Brooks, D. C. (2011). Space matters: The impact of formal learning environments on student learning. British Journal of Educational Technology, 42(5), 719-726. Retrieved from http://search.ebscohost. com/login. aspx?direct=true $\& d b=$ psyh\&AN=2011-18319-002\&site=ehost-live

Brooks, D. C. (2012). Space and consequences: The impact of different formal learning spaces on instructor and student behavior. Journal of Learning Space, 1(2).

Brooks, D. C., \& Solheim, C. A. (2014). Pedagogy Matters, Too: The Impact of Adapting Teaching Approaches to Formal Learning Environments on Student Learning. New Directions for Teaching \& Learning, 137, 53-61. doi:10.1002/tl.20085

Chen, V. (2015). "There Is No Single Right Answer": The Potential for Active Learning Classrooms to Facilitate Actively Open-Minded Thinking. Collected Essays on Learning and Teaching, 8, 171-180.Retrieved from http://search.ebscohost.com/login.aspx?direct=true\&db=eric\&AN=EJ10697 26\&site=ehost-live

Chiu, P. H. P., \& Cheng, S. H. (2017). Effects of active learning classrooms on student learning: a twoyear empirical investigation on student perceptions and academic performance. Higher Education Research \& Development, 36(2), 269-279. doi:10.1080/07294360.2016.1196475

Dori, Y. J., \& Belcher, J. (2005). How does technolgoy-enabled active learning affect undergraudate studetns understanding of electromagentism concepts. The Journal of the Learning Sciences, 14(2), 243-279. Retrieved from http://web.mit.edu/edtech/casestudies/pdf/teal1.pdf

Dori, Y. J., Belcher, J., Bessette, M., Danziger, M., McKinney, A., \& Hult, E. (2003). Technology for active learning. Materials Today (6), 44-49.Retrieved from http://web.mit.edu/edtech/casestudies/ pdf/teal2.pdf

Gordy, X.Z., Jones, E.M., \& Bailey, J.H. (2018). Technological Innovation or Educational Evolution? A Multi-disciplinary Qualitative Inquiry into Active Learning Classrooms. Journal of the Scholarship of Teaching and Learning, 18(2).

Gebre, E., Saroyan, A., \& Aulls, M. W. (2015). Conceptions of Effective Teaching and Perceived Use of Computer Technologies in Active Learning Classrooms. International Journal of Teaching and Learning in Higher Education, 27(2), 204-220.Retrieved from http://search.ebscohost.com/login.aspx? direct $=$ true \&db=eric\&AN=EJ1082880\&site=ehost-live

Guilford, J. P. (1950). Creativity. American Psychologist, 5, 444-454.

Guilford, J. P. (1977). Way beyond the IQ. Buffalo, NY: Bearly Limited.

Hartley, J., \& Davies, I. (1978). Note taking: a critical review. Programmed Learning and Educational Technology, 15, 207-224.

Hunley, S., \& Schaller, M. (2006). Assessing learning spaces. In D. G. Oblinger (Ed.), Learning spaces. 
Boulder, CO: Educause.

Lowerison, G., Sclater, J., Schmid, R. F., \& Abrami, P. C. (2006). Student Perceived Effectiveness of Computer Technology Use in Post-Secondary Classrooms. Computers and Education, 47(4), 465-489.Retrieved from http://search.ebscohost.com/login.aspx?direct=true\&db=eric\&AN= EJ739001\&site=ehost-live

Mackinnon, D. (1962). The nature and nurture of creative talent. American Psychologist, 17, 484-495.

Newble, D., \& Cannon, R. (1995). A Handbook for Teachers in Universities \& Colleges: A guide to improving teaching methods (3rd ed.). London: Kogan Page.

Park, E., \& Choi, B. (2014). Transformation of classroom spaces: traditional versus active learning classroom in colleges. Higher Education, 68(5), 749-771. doi:10.1007/s10734-014-9742-0

Puma, M., \& Abt Associates, I. C. M. A. (1996). Prospects: The Congressionally Mandated Study of Educational Growth and Opportunity. Findings from the 1992 Catholic School Supplement. Retrieved from http://search.ebscohost.com/login.aspx?direct=true\&db=eric\&AN=ED402657\&site=ehost-live

Roblyer, M. D. (2003). Integrating educational technology into teaching (3 ed.). Upper Saddle River, NJ: Merrill Prentice Hall.

Sherman, L. W. (1991). Cooperative Learning in Post Secondary Education: Implications from Social Psychology for Active Learning Experiences.

Smith, C. V., \& Cardaciotto, L. (2011). Is Active Learning Like Broccoli? Student Perceptions of Active Learning in Large Lecture Classes. Journal of the Scholarship of Teaching and Learning, 11(1), 53-61.Retrieved from http://search.ebscohost.com/login.aspx?direct=true\&db=eric\&AN=EJ9159 23\& site $=$ ehost-live

Swaray, R. (2012). An Evaluation of a Group Project Designed to Reduce Free-Riding and Promote Active Learning. Assessment \& Evaluation in Higher Education, 37(3), 285-292.Retrieved from http://search.ebscohost.com/login.aspx?direct=true\&db=eric\&AN=EJ962340\&site=ehost-live

Torrance, E. P. (1966). Torrance tests of creative thinking. Princeton, NJ: Personnel Press.

Torrance, E. P. (1970). Encouraging creativity in the classroom. Dubuque, IA: William C. Brown Company.

Torrance, E. P. (1983). The beyonders in a thirty year longitudinal study. Roeper Review, 15(3), $131-151$.

U.S. Department of Education. (2010, 2016, 2017). National Education Technology Plan. Retrieved from https://tech.ed.gov/netp/

Wankat, P. (2002). The effective efficicent professor: teaching, scholarship and service. Boston, MA: Allyn and Bacon.

Whiteley, T. R. (2007). Integrating the technological resources of the online learning environment with the vak learning-styles model to foster student learning. Paper presented at the AMA Winter Educators' Conference Proceedings. 